\title{
Salience and Similarity in Loanword Adaptation: a Case Study from Fijian
}

Michael Kenstowicz, MIT June 2003

The adaptation of a loanword involves the resolution of often conflicting demands to preserve as much information from the source word as possible while still satisfying the constraints that make the lexical item sound like a word of the recipient language. Prince and Smolensky's (1993) constraint-based Optimality Theory with its key notions of faithfulness and violable constraints is particularly well suited to model this aspect of linguistic competence. In adapting a foreign word the speaker is often faced with choices as to which information of the source to preserve and which to sacrifice. Recent study of this question suggests that auditory salience and similarity are critical factors in resolving the choice (Fleischacker 2000, Kenstowicz 2001, Steriade 2001a,b, Kang 2002, among others; see LaCharité and Paradis 2002 for a different perspective). The speaker will tend to preserve features whose absence would be most noticeable; and when a repair must be made, like a good tailor he will make his alterations as unobtrusive as possible by substituting a sound that most closely resembles the original.

In this paper we analyze the adaptation of English loanwords into Fijian from this perspective. The data and basic descriptive generalizations originate from a series of papers by Albert Schütz $(1978,1983,1985,1999)$. After a brief introduction we analyze the adaptation strategies employed to maintain the stress of the English source word in the face of the native metrical constraints. We then examine in turn the adaptation of consonant clusters, certain variations in the quality of the epenthetic vowel, and the substitution of voiced stops. The paper concludes with a summary of the main results.

\section{Background}

Fijian is probably best known in the generative tradition for its moraic trochee parse from the right edge of word and its reliance on trochaic shortening to maintain foot binarity and strict right-edge alignment (Blevins 1994, Hayes 1995). In the native system there is a vowel length contrast (1a). Syllables are parsed into bimoraic trochaic feet from right to left; the main stress of the word or phrase is located in the rightmost foot (1b). The right edge of the word is rigidly aligned with a foot. In case an underlying long vowel falls in the penult, it is shortened to satisfy foot alignment and bimoraic foot structure (1c). ${ }^{1}$

\footnotetext{
${ }^{1}$ The transcriptions are based on the Fijian orthography. Most symbols have their expected interpretation except that $b, d$, and $q$ denote prenasalized voiced stops $\left[{ }^{\mathrm{m}} \mathrm{b},{ }^{\mathrm{n}} \mathrm{d}\right.$, and ${ }^{\mathrm{n}} \mathrm{g}$ ] respectively while $v$ is a bilabial approximant, and $g$ is the velar nasal.
} 
(1)

a. kíla 'wild' vs. kilá: 'know it'

makáwa ‘old’ vs. mà:cáwa ‘week’ vs. màcawá:’worthless’ (S 1999:149)

b. kàtakáta 'hot', matànavótu 'visible world', vàkatà:kilá: 'reveal it' (S

1999:140)

c. tá: 'chop', tá-y-a 'chop it'

bú: 'grandmother', bu-qu 'my grandmother' (S 1985:528)

We will assume that the basic metrical parse is enforced by the constraints listed in (2).

Foot-Binarity: feet are composed of two moras.

Trochaic: the leftmost syllable of the foot is prominent.

Lapse: assign a penalty for each pair of adjacent unstressed syllables.

Align-Right: align the right edge of the prosodic word with a foot.

The Lapse constraint forces the insertion of metrical feet to avoid sequences of unstressed syllables while Foot-Binarity limits the size of the foot to two moras (a single heavy syllable or two light ones). Trochaic places the stress on the first syllable of a disyllabic foot as well as on a single heavy syllable. Align-Right requires the right edge of the word to coincide with a foot. The tableau in (3) indicates how the basic alternating stress pattern oriented at the end of the word is generated for a generic polysyllabic word by the constraints in (2).

$$
\mathrm{s}^{\prime}=\text { stressed syllable }
$$

\begin{tabular}{|l|l|l|l|l|}
\hline matanavotu & Ft-Bin & Trochaic & Lapse & Align-Rt \\
\hline (s's)(s's)(s') & $*$ & & & \\
\hline (s's)(s's)s & & & $*$ & $*$ \\
\hline (s s')(s s') s & & $*$ & & $*$ \\
\hline (s's)s(s's) & & & $*$ & \\
\hline -> s(s's)(s's) & & & & \\
\hline
\end{tabular}

Trochaic shortening is enforced by the ranking in (4).

$$
\text { Ft-Bin, Align-Rt >> Max-Mora }
$$

An underlying long vowel will lose a mora and hence violate Max-Mora in order to maintain a bimoraic foot that is aligned with the right edge of the word. (cf. Tongan 
(Prince \& Smolensky 1993) where a long vowel is broken into two syllables in the same position). The shortening of penultimate vowels is calculated in (5).

(5)

\begin{tabular}{|l|l|l|l|}
\hline /bu:-qa/ & Ft-Bin & Align-Rt & Max-Mora \\
\hline (bú:)qa & & $* !$ & \\
\hline (bú:qa) & $* !$ & & \\
\hline$->$ (búqa) & & & $*$ \\
\hline
\end{tabular}

\section{Accentual Adaptation}

With this background we now turn to the adaptation of loanwords. This topic has been pursued by Albert Schütz $(1978,1983,1999)$ on the basis of an original corpus of c. 800 words (the appendix to Schütz 1978). Fijian is an open syllable language. Extensive vowel epenthesis is employed to break up consonant clusters inherited from the source language. With regard to accent, two generalizations stand out. First, Fijian does its best to ensure that the main stress of the English source is matched by a stress in the adapted loan. This is achieved by either allowing a lapse in the alternating stress pattern or by lengthening a vowel to satisfy foot binarity. Second, the language also strives to avoid stressing inserted vowels or otherwise render them prominent. Since stress is not marked orthographically (in either the source or the adaptation), it is clear that we are dealing with an active linguistic computation rather than simple mimicking of written forms. Also, because stress is largely predictable in Fijian, a non-distinctive but salient feature of the grammar actively shapes the adaptation.

\subsection{Repair 1: Lengthening}

In (6) we illustrate contrasting stress contours on adaptations with an equivalent number of syllables. The accentual contrasts in these loanwords are predictable on the basis of the location of main stress in the English source word.

$\begin{array}{cllll}\text { (6) } & \underline{\text { English }} & \underline{\text { Fijian }} & \underline{\text { English }} & \underline{\text { Fijian }} \\ \text { a. } & \begin{array}{l}\text { cólony } \\ \text { táffeta }\end{array} & \begin{array}{l}\text { kò:lóni } \\ \text { tà:féta }\end{array} & \begin{array}{l}\text { tobácco } \\ \text { pajáma }\end{array} & \begin{array}{l}\text { taváko } \\ \text { pajáma }\end{array} \\ \text { b. } & \text { jélly } & \text { jéli } & \text { bazáar } & \text { bazá: } \\ & \text { féver } & \text { fíva, víva } & \text { guitár } & \text { qitá: }\end{array}$




$\begin{array}{lllll}\text { c. } & \begin{array}{l}\text { cábin } \\ \text { léttuce }\end{array} & \begin{array}{l}\text { kè:bíni } \\ \text { lè:tísi }\end{array} & \begin{array}{l}\text { ballóon } \\ \text { percént }\end{array} & \begin{array}{l}\text { balúni } \\ \text { paséde }\end{array} \\ \text { d. } & \begin{array}{l}\text { spínach } \\ \text { stócking }\end{array} & \begin{array}{l}\text { sipì:níji } \\ \text { sitò:kígi }\end{array} & \begin{array}{l}\text { básket } \\ \text { cústom }\end{array} & \begin{array}{l}\text { bàsikéti } \\ \text { kàsitába }\end{array}\end{array}$

In (6a) vowel length is inserted to ensure that a bimoraic foot can be formed so as to situate stress on the vowel whose correspondent is stressed in the source language. Thus, in proparoxytone cólony -> [kò:lóni] the first syllable is lengthened. The paroxytone tobácco requires no lengthening since the first syllable is unstressed in the English source. Formally, there are two ways in which we could conceive of this contrast. Either the stress of the source word is translated into a Fijian stress in an initial "perceptual scan" (Silverman 1992), or it arises in the production side of the grammar through the intervention of a faithfulness constraint that tries to match the stress of the English source word with a stress in the Fijian adaptation (as in Davidson and Noyer's 1995 analysis of Spanish loans into Huave). Obviously, either analysis makes sense only in the initial phase of loanword adaptation when the adapter is cognizant of the English source. Once the loan has been incorporated into the native lexicon, it may be regularized if the source is no longer known or recognized. It is unclear to what extent this has happened in Fijian, though Schütz (1990) mentions that loans of the structure CV:CVCV may shorten their vowel and hence lose all trace of their English provenance: cf. bì:kéni'beacon' > bikéni. Loanword adaptations such as those in (6) result in the typological oddity where main stress is predictable but secondary stress is not (Hayes 1995). For concreteness, we will assume that the main stress of the English source is incorporated into the lexical representation of the Fijian adapted form rather than computed on-line.

Let us examine the data from (6) in more detail. First, we consider the proparoxytone cólony. Assuming that the Fijian input has lexicalized the English main stress, a Max-Stress constraint forcing the metrical parsing to respect this stressed vowel must be highly ranked. In particular, it necessitates the insertion of a mora. Hence, MaxStress (preserve the stress of the lexicalized input) dominates the constraint Dep-Mora that penalizes the insertion of a mora. (We consider later an alternative interpretation according to which all stressed vowels of the source are lexicalized as long vowels). Our analysis abstracts away from the distinction between primary and secondary stress in Fijian.

\begin{tabular}{|l|l|l|l|}
\hline /cólony/ & Align-Rt & Max-Str & Dep-Mora \\
\hline (kólo)ni & $* !$ & & \\
\hline
\end{tabular}




\begin{tabular}{|l|l|l|l|}
\hline ko(lóni) & $* !$ & $*$ & \\
\hline$->$ (kó:)(lóni) & & & $*$ \\
\hline
\end{tabular}

There is another candidate that must be considered, however. Given that length can be inserted to achieve foot binarity, what is wrong with (kólo)(ní:)? As shown in (8), it aligns the right edge of the word with a foot, copies the main stress of the English source, and adds a mora. Its constraint violation profile is thus comparable to (kó:)(lóni).

(8)

\begin{tabular}{|l|l|l|l|}
\hline /cólony/ & Align-Rt & Max-Str & Dep-Mora \\
\hline (kólo)(ní:) & & & $*$ \\
\hline (kó:)(lóni) & & & $*$ \\
\hline
\end{tabular}

Moreover, both kò:lóni and kòloní: match valid native Fijian metrical structures: cf. mà:cáwa 'weak' vs. màcawá: 'worthless'.

We suggest that (kó:)(lóni) is chosen over (kólo)(ní:) on the basis of relative auditory similarity to the source along a dimension of Prosodic Prominence. We postulate the hierarchy in (9) which ranges from a vowel to a stressed vowel and finally to a stressed long vowel.

$$
\text { Prosodic Prominence: } \mathrm{V}<{ }^{\prime} \mathrm{V}<{ }^{\prime} \mathrm{V} \text { : }
$$

The idea is that lengthening the first vowel of /kóloni/ is less of a departure from the source cólony than lengthening the final one. Note that simply counting the inserted stresses and lengths fails to discriminate the two candidates: both (kó:)(lóni) and (kólo)(ní:) insert an extra stress and a mora. What makes (kólo)(ní:) worse is that both insertions are localized in the same vowel. Hence it is a greater auditory departure from the source than is (kó:)(lóni), which distributes the violations through the word.

Violations can be calculated in terms of the total number of steps along the hierarchy or in terms of violations at discrete points in the representation. We adopt the latter interpretation. On this view, the mapping from /ni/ to [ní:] in the adaptation of cólony traverses two steps along the prominence scale of (9) while the winning candidate has two mismatches of one step each: [ó] to [ó:] and [o] to [ó]. Simply summing the violations over the whole word would fail to distinguish between the two candidates.

*PP-2 >> *PP-1 


\begin{tabular}{|l|l|l|}
\hline /cólony/ & *PP-2 & *PP-1 \\
\hline$->$ (kó:)(lóni) & & ó:, ó \\
\hline (kólo)(ní:) & í:! & \\
\hline
\end{tabular}

The adaptation of the paroxytone taváko (6b) as ta(váko) rather than as (tá:)(váko) shows that a mora is not inserted simply to parse more syllables into metrical feet. Once again the Prosodic Prominence similarity metric rules out this mapping.

\begin{tabular}{|l|l|l|}
\hline /taváko/ & *PP-2 & *PP-1 \\
\hline -> ta(váko) & & \\
\hline (ta:)(váko) & á:! & \\
\hline
\end{tabular}

Paroxytone jélly and féver are adapted straightforwardly as Fijian (jéli) and (fíva) while oxytone bazáar and guitár require the insertion of a mora to sustain the final stress: ba(zá:) and qi(tá:).

The adaptations of cábin and ballóon (kè:bíni and balúni) in (6c) work as predicted. They differ from cólony and tobácco only in having a final vowel that is inserted rather than inherited from the source. As we shall see, Fijian avoids stressing an epenthetic vowel if possible (Shinohara's 1997 *`v) and so the (kébi)(ní:) parse will be rejected in any case. The similarity metric also correctly chooses (ké:)(bíni) because lengthening a stressed vowel ('V $>^{\prime} \mathrm{V}$ :) is less of a departure from the source than lengthening and stressing a vowel whose correspondent in the source is zero $\left(\varnothing>{ }^{\prime} \mathrm{V}\right.$ :).

\begin{tabular}{|c|c|c|c|c|}
\hline /cábin/ & Max-Str & *'v & PP-2 & PP-1 \\
\hline ->(ké:)(bíni) & & & & é:, í, \\
\hline ke(bíni) & $* !$ & & & í, \\
\hline (kébi)(ní:) & & í:! & í: & \\
\hline
\end{tabular}

\begin{tabular}{|l|l|l|l|l|}
\hline /ballóon/ & Max-Str & *’v & PP-2 & PP-1 \\
\hline (bá:)(lúni) & & & á:! & \\
\hline ->ba(lúni) & & & & \\
\hline
\end{tabular}




\begin{tabular}{|l|l|l|l|l|}
\hline (bálu)(ní:) & $* !$ & í: & í: & á \\
\hline
\end{tabular}

Our analysis also chooses the correct output candidate for spinach in (6d). Preference for inserting length on the correspondent of a stressed vowel of the source blocks si(píni)(jí:) in favor of si(pí:)(níji).

\begin{tabular}{|l|l|l|l|}
\hline /spínach/ & *’v $^{\prime}$ & PP-2 & PP-1 \\
\hline ->si(pí:)(níji) & & & í:, í \\
\hline si(píni)(jí:) & í:! & í: & \\
\hline
\end{tabular}

In the adaptation of básket as (bási)(kéti) we see that epenthetic vowels are visible to the metrical parse. If they were invisible we would expect just a single stress located on the first syllable of a bimoraic foot composed of the vowels with correspondents in the English source: básiketi. Moreover, the fact that the stressed vowels of bàsikéti are not lengthened shows that the inserted vowels contribute a mora to the foot to achieve binarity in the same way as an underlying vowel does.

\subsection{Repair-2: Lapses}

Let us now turn to the analysis of longer words. Examples appear in (14).

$\begin{array}{llll}\text { English } & \text { Fijian } & \text { English } & \text { Fijian } \\ \text { éstimate } & \text { èsitiméti } & \text { président } & \text { perèsi.tédi } \\ \text { télegraph } & \text { tàlekarávu } & \text { crócodile } & \text { koròkotáile } \\ \text { télevision } & \text { tàlevisóni } & \text { appéndix } & \text { apènidíki }\end{array}$

Adaptations such as crócodile $>$ koròkotáile have a smoothly alternating WSWSW stress contour that matches the main stress of the source. But formations such as tàlevisóni (télevision) and pàrakarávu ( páragraph) contain a lapse in stress. The Max-Stress constraint rejects the rhythmically optimal WSWSW alternating stress pattern of candidates ta(lévi)(sóni) and pa(ráka)(rávu). But why isn’t the stressed vowel lengthened to give (tá:)(lévi)(sóni) and (pá:)(ráka)(rávu)? As we have seen, a trisyllabic adaptation whose initial syllable is stressed in the source systematically tolerates a stress clash: 
cólony -> (kó:)(lóni). But longer words avoid a clash in favor of a lapse: télevision > tàlevisóni. Constraint ranking can account for this difference. Max-Stress $>>$ Clash forces a clash. But when Max-Stress is satisfied then a lapse is preferred to a clash: Clash $>>$ Lapse.

\begin{tabular}{|l|l|l|}
\hline /télevision/ & Clash & Lapse \\
\hline$->$ (tále)vi(sóni) & & $*$ \\
\hline (tá:)(lévi)(sóni) & $* !$ & \\
\hline
\end{tabular}

Earlier we saw that Prosodic Prominence-2 rejected final stress (kòlo)(ní:) in favor of (kò:)(lóni). We must conclude that PP-2 dominates Clash.

\begin{tabular}{|l|l|l|}
\hline /cólony/ & PP-2 & Clash \\
\hline (kólo)(ní:) & í:! & \\
\hline$->$ (kó:)(lóni) & & $*$ \\
\hline
\end{tabular}

The Hasse diagram in (17) summarizes the crucial constraint rankings in our analysis. The upper stratum is composed of the constraints on foot form (binarity and trochaic) and the right-edge alignment. The Max-Stress constraint is specific to the loanword phonology, where the speaker tries to accommodate the two most auditorily salient features of English and Fijian: their primary stressed syllables. This may necessitate the violation of constraints on good rhythmic form (Clash and Lapse). When there is a choice as to where to lengthen a vowel to achieve a binary foot (as in (kó:)(lóni) vs. (kólo)(ní:) ) the Prosodic Prominence constraint resolves the choice in favor of the former where the augmentation is presumably less noticeable.

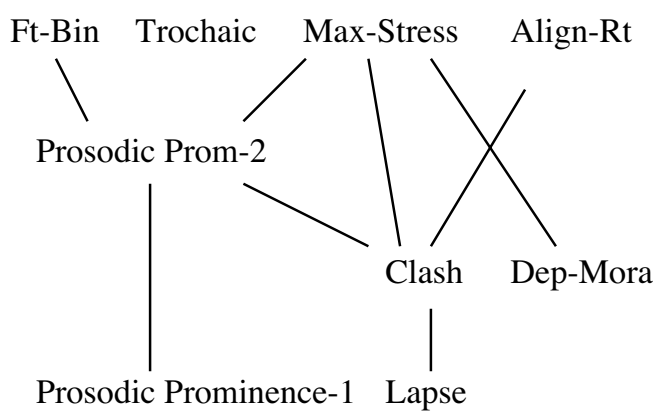


The Clash >> Lapse ranking that chooses (tále)vi(sóni) over (tá:)(lévi)(sóni) may also reflect faithfulness to the source by avoiding a stress that does not otherwise correspond to one from English (entailing PP-1 >> Lapse). However, Schütz (1999) points out that there are Lapse violations within Fijian itself in formations with an internal juncture such as certain reduplications (sàvasavá: ‘clean', qìqo.qiqóra 'thickset) and compounds (bàtikacíwa 'kind of bird', bátikasívi 'kind of fish'). To the extent that these items are no longer decomposed in the minds of Fijian speakers, there is a precedent for the lapses observed in loans. And we recall that according to Schütz (1990) when the words with a clash such as beacon > bì:kéni are nativized, the original stress is lost (presuambly because stress is not lexical in Fijian) and the clash is eliminated: bikéni.

In the next section we turn to the other aspect of Fijian stress faithfulness: the skipping of inserted vowels.

2. $3 * v^{\prime}$

It is well known that epenthetic vowels are often invisible to stress processes (Broselow 1982). This phenomenon has received several formal treatments in the recent literature (Hagstrom 1997, Alderete 1999). In the context of loanword adaptation, Shinohara's (1997, 2000) study of Japanese adaptations of French loans observes that the expected default antepenultimate accent is suspended when stress would fall on an inserted vowel (machicoulis $>$ masi'kuri but abricot $>$ aburi'ko) and attributes it to a general principle of Minimal Saliency for epenthetic vowels: *`v. Steriade $(2001 \mathrm{a}, \mathrm{b})$ places this idea in a broader context. Since an epenthetic vowel has a zero correspondent in the input, any process that enhances the prominence of a vowel will make it less auditorily similar to its source. Hence, epenthetic vowels tend to be short, lax vowels that often lack their own inherent features and acquire them from the local context instead-another strategy to render them inconspicuous and thus closer to zero.

The data in (18) show that inserted vowels in Fijian adaptation shun accent (a point noted explicitly by Schütz 1978, 1983). When the penultimate syllable arises from epenthesis then the accent systematically shifts to the final vowel, which is lengthened to satisfy binarity.

$\begin{array}{lll}\text { whísky } & \text { wìsikí: } & \text { sílver } \\ \text { bátt<e>ry } & \text { bàtirí: } & \\ \text { dóctor } & \text { dòketá: } & \end{array}$

\footnotetext{
${ }^{2}$ This word appears to have been integrated into Fijian to the extent that the stress of the source word as well as its epenthetic vowel is no longer recognized.
} 


$\begin{array}{ll}\text { síster } & \text { sìsitá: } \\ \text { máster } & \text { màsitá: } \\ \text { rúgby } & \text { ràkaví: } \\ \text { úlcer } & \text { àlasá: }\end{array}$

An adaptation such as whísky > wìsikí: contrasts strikingly with cólony > kò:lóni. We appealed to the ranking PP-2 >> PP-1 in (10) to explain why length is inserted on the stressed vowel in cólony > kò:lóni rather than on the final syllable. Since final stress is precisely the outcome seen in whisky > wisikí:, we conclude that ${ }^{*} \mathrm{v}$ ' dominates PP-2.

\begin{tabular}{|l|l|l|}
\hline /whisky/ & $*^{*}$ ' & PP-2 \\
\hline (wí:)(síki) & $* !$ & \\
\hline (wísi)(kí:) & & í: \\
\hline
\end{tabular}

The data in (18) such as whísky > wissikí: demonstrate that length can be added to a vowel in order to seat a stress and satisfy foot binarity. It shows that not all long vowels in Fijian adaptations can be attributed to a putative equation of stress $=$ length at the level of the perceptual scan (Silverman 1992). We therefore conclude that the main stress of English is translated as a stress in Fijian rather than as a length that in turn attracts a stress. Also, to the extent that nativizations such as bì:kéni > bikéni occur, they make sense as the loss of (unpredictable) stress in a system where stress is otherwise not lexically contrastive. But they would remain mysterious as the loss of length since length is contrastive in Fijian.

There are also cases where a long vowel that is not the site of main stress in the English source is preserved in the adaptation process and then attracts stress. One case consists of long vowels preceding the main stress of English. The other is a final long vowel. While the former is systematic the latter seems much less so.

$\begin{array}{ll}\text { English } & \underline{\text { Fijian }} \\ \text { oméga } & \text { ò:méka } \\ \text { hosánna } & \text { ò:sána } \\ \text { tomáto } & \text { tò:máta } \\ \text { torpédo } & \text { tò:píto } \\ \text { cárgo } & \text { kà:kó: }\end{array}$




$\begin{array}{cll} & \text { cálico } & \text { kàli.kó: } \\ \text { pólio } & \text { pòli.ó: } \\ & \text { rádio } & \text { rèti.ó: } \\ \text { but } & \text { mángo } & \text { máqo } \\ & \text { tabácco } & \text { taváko }\end{array}$

The inviolable requirement that the main stress be located in one of the final two syllables of the word overrides the ban against stressing an inserted vowel. This is shown by words ending in a cluster of consonants that are adapted with a double epenthesis.

$\begin{array}{llll}\text { belt } & \text { bè:léti } & \text { silk } & \text { silíka } \\ \text { dance } & \text { dà:nísi } & & \\ \text { film } & \text { fì:límu } & \\ \text { fox } & \text { fò:kísi } & \end{array}$

The tableau in (22) shows the derivation of these forms. The candidate béleti is rejected by Align-Rt. But both the first and third candidates tie on *v'. Earlier (16) we saw the PP-2 constraint choose the clashing stresses of kò:lóni over kòloní:. Evidently the same calculation is being made in (22) even though both vowels are inserted and hence have zero as their input correspondent. In terms of auditory saliency it seems clear that the pair $\left.\left(\varnothing-\mathrm{V}^{\prime}\right)^{\prime}\right)$ is more distinct and hence less optimal than $\left(\varnothing-\mathrm{V}^{\prime}\right)$.

\begin{tabular}{|l|l|l|l|}
\hline /bélt/ & Align-Rt & $* \mathrm{v}$ & $\mathrm{PP}-2$ \\
\hline -> (bé:)(léti) & & $*$ & \\
\hline (béle)ti & $* !$ & & \\
\hline (béle)(tí:) & & $*$ & $* !$ \\
\hline
\end{tabular}

\footnotetext{
${ }^{3}$ Like siliva $<$ silver this word also appears to have been integrated into Fijian to the extent that the stress of the source word as well as its epenthetic vowel are no longer recognized.
} 
The diagram in (23) summarizes the analysis to this point with regard to the ranking of $* v$ '.

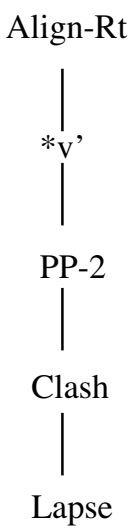

There are a couple of additional words in the corpus that allow us to solidify the ranking of $* v$ '. Since $*^{*}$ ' dominates Lapse we predict that a lapse will be preferred to stressing an inserted vowel. We have been able to find one word in the corpus that bears on this prediction (and confirms it): chémistry > kè:mìsitirí:. The alternating stress of the rhythmically optimal (kémi)(síti)(rí:) is rejected in favor of a candidate (ké:)(mísi)ti(rí:) that suffers from both a clash and a lapse. The candidate (kémi)si(tíri) eliminates the clash. But this is not good enough since it still stresses an inserted vowel in contravension of the $* v^{\prime}>>$ Lapse ranking. ${ }^{4}$

\footnotetext{
${ }^{4}$ The tendency for the regular metrical parse to avoid stressing epenthetic vowels (formalized here as *v') calls into question the interpretation of the ebzo...ebuzo equivalence reported by Dupoux et al 1999. In one of their experiments Japanese and French listeners are played a series of stimuli in which the medial [u] vowel of a stimulus like ebuzo is truncated by $18 \mathrm{~ms}$. intervals. Subjects are asked if they hear the medial vowel. French subjects report presence of the vowel over a significantly greater range of the stimuli than Japanese listeners do. The authors suggest that Japanese speakers assign a consonantal stimulus to a CV template at a very early - pregrammatical - stage of speech perception, reflecting the fact that it is a CV open syllable language. The vowel is identified as $[\mathrm{u}]$ because it is the shortest and most malleable vowel in the Japanese phonemic inventory. French speakers do not automatically hear a vowel after every consonant since French has consonant clusters. The problem for this view is that-barring some ad hoc representational difference - the default accent process of the Japanese production grammar will be unable to distinguish an $[\mathrm{u}]$ that arises from epenthesis from one that is underlying. The fact that the metrical accent of both Japanese and Fijian distinguishes inserted vowels suggests that medial consonant clusters are accurately perceived and lexicalized so that the *v' constraint has access to the zero correspondent. One possible explanation for Dupoux et al's experimental results, suggested by Donca Steriade (personal communication), is that "Japanese speakers are aware of epenthesis in their own speech so that a cluster $\mathrm{C}_{\mathrm{i}} \mathrm{C}_{\mathrm{j}}$ is perceived as equivalent to $\mathrm{C}_{\mathrm{i}} \mathrm{uC}$ and thus any $\mathrm{C}_{\mathrm{i}} \mathrm{C}_{\mathrm{j}}$ percept corresponds to a $\mathrm{C}_{\mathrm{i}} \mathrm{uC}$, production". This predicts that if the experiment were repeated by successive compression of a different vowel (e.g. ebzo...ebozo) Japanese subjects will more closely approximate French ones since [o] is not an epenthetic vowel (except in restricted circumstances--see below).
} 


\begin{tabular}{|l|l|l|l|}
\hline /chémistry/ & *v' & Clash & Lapse \\
\hline$->$ (ké:)(mísi)ti(rí:) & & $*$ & $*$ \\
\hline (kémi)(síti)(rí:) & $* !$ & & \\
\hline (kémi)si(tíri) & $* !$ & & $*$ \\
\hline
\end{tabular}

A final point needs to be made regarding the adaptation of chémistry to kè:misitirí:. What is wrong with the candidate (kémi)siti(rí:) where both inserted vowels are unstressed? Since Clash dominates Lapse this candidate should beat out (ké:)(mísi)ti(rí:).

\begin{tabular}{|l|l|l|}
\hline /chémistry/ & Clash & Lapse \\
\hline (ké:)(mísi)ti(rí:) & $*$ & \\
\hline$*($ kémi)siti(rí:) & & $* *$ \\
\hline
\end{tabular}

This datum suggests that we distinguish two sorts of lapses. The constraint that Green \& Kenstowicz (1995) dub Lapse and that Elenbas and Kager (1999) call Parse-2 is helpful here. (We conflate the nomenclature to Lapse-2).

Lapse-2: penalize a sequence of two unstressed syllables not separated by a foot boundary.

Lapse-1: penalize a sequence of two unstressed syllables.

If Lapse-2 dominates Clash then the (kémi)siti(rí:) candidate is correctly eliminated before the Clash constraint assesses its penalty against (ké:)(mísi)ti(rí:) (27)

\begin{tabular}{|l|l|l|}
\hline /chémistry/ & Lapse-2 & Clash \\
\hline (ké:)(mísi)ti(rí:) & & $*$ \\
\hline (kémi)siti(rí:) & $* !$ & \\
\hline
\end{tabular}

Now consider proféssor $>$ porò:fésa. We must account for the clashing stress on the second syllable. One possibility is that it follows the pattern of oméga >ò:méga with stress falling on a long vowel. But proféssor may also be pronounced with a reduced initial vowel in English. If the Lapse-2 constraint is high-ranking it will force the 
insertion of a stress over one of the first two syllables of the word. *v' will reject initial stress leaving the clashing stress of porò:fésa as the best alternative.

(28)

\begin{tabular}{|l|l|l|l|}
\hline /proféssor/ & Lapse-2 & $*_{\mathrm{v}}$ & Clash \\
\hline poro(fésa) & $* !$ & & \\
\hline (pòro)(fésa) & & $* !$ & \\
\hline$->$ po(ró:)(fésa) & & & $*$ \\
\hline
\end{tabular}

A high-ranking Lapse-2 can also help us account for the stress that is inserted in initial clusters that undergo a double epenthesis.

$\begin{array}{ll}\text { scrum } & \text { sìkarámu } \\ \text { spring } & \text { sìpirígi } \\ \text { strike } & \text { sìtaráke }\end{array}$

Since ${ }^{*} \mathrm{v}$ ' dominates Clash which in turn dominates Lapse, without Lapse-2 the analysis predicts that Fijian adaptations will avoid stressing an inserted vowel and hence both epenthetic syllables in the adaptation of $\# s C$ clusters should be unstressed. But if Lapse-2 dominates $* \mathrm{v}$ ', then a stress must be inserted into one of the first two syllables of the word. Lower ranking PP-2 eliminates the candidate that stresses the second syllable.

\begin{tabular}{|l|l|l|l|}
\hline /scrúm/ & Lapse-2 & $*_{\mathrm{v}}$ & $\mathrm{PP}-2$ \\
\hline sika(ráma) & $* !$ & & \\
\hline -> (síka)(ráma) & & $*$ & \\
\hline si(ká:)(ráma) & & $*$ & $* !$ \\
\hline
\end{tabular}

The diagram in (31) summarizes the ranking of *v'.

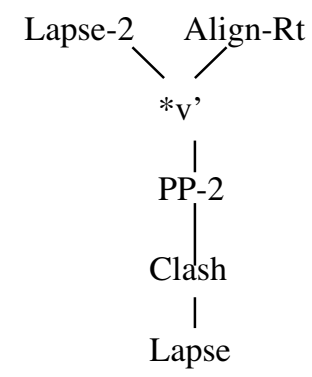


Stepping back from the details of the analysis, we see that the accentual adaptations accommodate two of the most salient features of the English and Fijian word: their main stresses. A stress is consistently assigned at these two points in the adaptation: via the undominated Max-Stress for the former and the Align-Right and Foot-Binarity for the latter. In some cases the two stresses coincide (bazáar -> bazá:, jélly -> jéli) but in most cases they do not. Faithfulness to the English stress is achieved at the cost of violations on good rhythmic form (the clash in cólony -> kó:lóni and the lapse in télevision -> tálevisóni) in a manner that is reminiscent of the "cyclic" transfer of stress from a base to a derived stem in languages such as Indonesian (Cohn and McCarthy 1994/1998, Kenstowicz 1995). Auditory salience also figured into the analysis in the guise of the ${ }^{*} \mathrm{v}$ ' constraint forcing a clash (proféssor $->$ porò:fésa) or a clash and a lapse (chémistry -> kè:mìsitirí:). But unlike Max-Stress, *v' is not inviolable because it is subordinated to the requirement that the right edge of the word align with a foot ( belt $->$ bè:líti) as well as the requirement that a stress be found in one of the first two syllables of the word (strike -> sìtaráke.

\section{The Adaptation of Consonant Clusters}

The relative saliency of phonological segments plays a significant role at another point in Fijian adaptations. Fijian is an open syllable $\{C V, V\}$ language. Like penultimate stress, this prosodic structure is rigidly enforced in loan adaptations: every consonant must be followed by a vowel. The major repair strategy is epenthesis. But truncation is also found. Examples appear in (32).

$\begin{array}{lll}\text { initial: } & \begin{array}{l}\text { English } \\ \text { steak } \\ \text { class }\end{array} & \begin{array}{l}\text { Fijian } \\ \text { sitéki } \\ \text { kalási }\end{array} \\ \text { medial: } & \begin{array}{l}\text { telegram } \\ \text { whisky }\end{array} & \begin{array}{l}\text { tàlikarámu } \\ \text { wìsikí: }\end{array} \\ & \text { ulcer } & \text { àlasá: } \\ \text { final: } & \text { barracks } & \text { bà:.réki } \\ & \text { billiards } & \text { bìli.áti } \\ & \text { film } & \text { fì:.límu } \\ & \text { ounce } & \text { ò:.nísi } \\ & \text { somersault } & \text { sàmi.sólo }\end{array}$


The truncation of word-final clusters in the face of general epenthesis elsewhere has been observed for loan adaptations in other CV languages (cf. Silverman 1992 for Cantonese, Brasington n.d. for Marshallese, and Gbéto 1999, Kenstowicz 2001 for Fon ). This disparity makes sense in perceptual terms since the second element in a word-final consonant cluster lacks formant transitions from an adjacent vowel that are a major cue to its place of articulation.

A closer examination of the adaptation of final clusters is summarized in (33). It strengthens this perceptual hypothesis.

$\begin{array}{lll}\text { obstr-obstr: } & \begin{array}{r}\mathrm{C}<\mathrm{C}>\mathrm{N}=20 \\ \text { east ísi }\end{array} & \begin{array}{l}\mathrm{CVCV} \\ \text { fox }\end{array} \text { fò:kísi } \\ \text { sonor-obstr: } & \mathrm{C}<\mathrm{C}>\mathrm{N}=12 & \mathrm{CVCV} \mathrm{N}=28 \\ & \text { gold goúla } & \text { wolf ò:líva }\end{array}$

The following points are worthy of note. First, while a single final consonant is uniformly repaired by epenthesis (bet $>$ béti), many final clusters truncate. Second, when truncation occurs it always eliminates the second consonant of the cluster-the one that is most lacking in cues (and the one which would be most noticeably changed with respect to the source if epenthesis did occur by placing it in the salient prevocalic position; cf. Wilson 2001). Third, there is a divergence in the clusters themselves. When the first consonant of the cluster is an obstruent then deletion is five times more likely than epenthesis. But when the first consonant is a sonorant, then epenthesis is more than twice as likely as truncation. This contrast also makes sense in perceptual terms. Sonorant consonants have formant structure and so are able to cue the following consonant better than an obstruent (albeit not as robustly as a vowel).

There is one other difference in the treatment of word-final clusters that is worth observing: a nasal followed by voiced vs. voiceless stop, in particular/nt/ vs. /nd/.

$$
\begin{aligned}
& \begin{array}{llll}
\mathrm{nt} & \mathrm{n}<\mathrm{t}>\mathrm{N}=2 & \mathrm{ndV} \quad \mathrm{N}=13
\end{array} \\
& \text { sergeant sà:tíni elephant èlevádi = èlevá. }{ }^{n} \text { di } \\
& \text { nd: } \quad \mathrm{n}<\mathrm{d}>\quad \mathrm{N}=4 \quad \mathrm{ndV} \quad \mathrm{N}=3 \\
& \text { band báni almond à:módi = à:mó. }{ }^{\mathrm{n}} \mathrm{di}
\end{aligned}
$$

For the former $\mathrm{C}_{2}$ almost always survives (sérgeant $>$ sà:tíni and ágent > itíni are the exceptions) while for the latter the number of deletions is roughly comparable to the number of epentheses. Although the numbers are too small to make meaningful statistical 
tests, they are suggestive and go in the direction one would expect if auditory salience is the relevant point on which deletion vs. epenthesis is turning. /nt/ and /nd/ are equivalent on transition cues but /nt/ has a syntagmatic contrast in voice that /nd/ lacks. ${ }^{5}$ Another factor that could be at play is that English VNT sequences are often realized by deletion of the nasal and nasalization of the vowel (Malécot 1960) while the nasal is typically preserved before a voiced consonant. Hence, if $/ \mathrm{Vnt} /$ is canonically realized as $[\sim \mathrm{Vt}]$ in English then it becomes equivalent to the case of a single final consonant, where epenthesis is uniform. (See Shinohara 2003 for extensive discussion of the role of salience in the adaptation of medial vs. final clusters in a variety of languages).

\section{Epenthetic Vowel}

In the Fijian corpus the choice of the epenthetic vowel appears to be more variable than in some other corpora discussed in the recent loanword literature. In part this is to be explained by the fact that loanwords have entered the language via different dialects and over a stretch of at least 150 years. Schütz (1978) discusses this question in some detail. We review here a couple of his findings and place them in a more general theoretical context.

First, Schütz finds a striking disparity between the distributions of vowels inserted to repair violations of the open-syllable canon in loan adaptations vs. their frequency rank in Fijian running text.

$\begin{array}{llll}\text { loans } & & \text { texts } & \\ \mathrm{i} & 61 \% & \mathrm{a} & 43 \% \\ \mathrm{e} & 15 & \mathrm{i} & 18 \\ \mathrm{a} & 12 & \mathrm{o} & 14 \\ \mathrm{u} & 7 & \mathrm{u} & 12 \\ \mathrm{o} & 5 & \mathrm{e} & 10\end{array}$

In loans over $75 \%$ of the inserted vowels are drawn from the (upper) front region of the vowel space that is occupied by [i] and [e]. In the native Fijian lexicon, on the other hand, the more widely dispersed [a], [i], and [u] account for a comparable range of territory. This makes sense under the principle of Minimal Saliency that calls for the inserted vowel to be the shortest and/or have its place features determined by the surrounding consonantal context. Given that in general higher vowels are shorter than lower vowels (Lehiste 1970), the preponderance of [i] makes sense. In terms of Steriade's (2001a,b)

\footnotetext{
${ }^{5}$ See Côté (2000) for discussion of syntagmatic contrast in consonant cluster resolution.
} 
Similarity model of faithfulness, we may infer from the presumed auditory judgment $\Delta$ $(\varnothing-e)>\Delta(\varnothing-i)$ (the difference between zero and [e] is greater than the difference between zero and [i]) the UG ranking * $\emptyset$-e $>>*_{\emptyset-\mathrm{i}}([\mathrm{i}]$ is preferred to [e] as the epenthetic vowel-the vowel whose input correspondent is zero). On the other hand, in the native Fijian system where vowels encode lexical items, dispersion across the vowel space is favored.

Second, Schütz (1978) notes an intriguing difference between the dental stops [t, $\left.{ }^{\mathrm{n}} \mathrm{d}\right]$ vs. [s, n] in determining the choice between [i] and [e] as the repair vowel in loans.

After [s, n] [i] is chosen in the overwhelming majority of cases. But after [t, $\left.{ }^{\mathrm{n}} \mathrm{d}\right]$, there are a substantial number of loans where the epenthetic vowel is the mid vowel [e].

$\begin{array}{lll} & \underline{\mathrm{i}} & \mathrm{e} \\ \mathrm{s} & 88 & 5 \\ \mathrm{n} & 92 & 4 \\ \mathrm{t} & 47 & 37 \\ \mathrm{n} d & 76 & 20\end{array}$

In (37) we report our count of word-final epenthetic vowels after [s] vs. [t] in the Schütz corpus, followed by a few examples.

$\begin{array}{llll} & \mathrm{i} & \mathrm{e} & \text { other } \\ \mathrm{s} & 45 & 5 & 1 \\ \mathrm{t} & 37 & 32 & 5\end{array}$

$\begin{array}{lllll}\text { /s\#/ } & \text { English } & \underline{\text { Fijian }} & \underline{\text { English }} & \underline{\text { Fijian }} \\ \text { dress } & \text { dresi } & \text { molasses } & \text { mala:sese } \\ \text { class } & \text { kalasi } & & \\ \text { nurse } & \text { nasi } & & \\ \text { toast } & \text { tosi } & & \\ \text { bus } & \text { basi } & & \\ & & \text { rabbit } & \text { ra:vete } \\ \text { tt\#/ } & \text { siviriti } & \text { coat } & \text { kote } \\ & \text { goat } & \text { koti } & \text { yard } & \text { yate } \\ \text { senate } & \text { seneti } & \text { biscuit } & \text { bisikete } \\ \text { velvet } & \text { veleveti } & \text { shout } & \text { saute } \\ \text { barmaid } & \text { ba:meti } & & \end{array}$


What could account for this difference? Schütz points out (1978:27) that in numerous Fijian dialects including Lauan (the source of many early borrowings) [t] is palatalized to [t $\left.\int\right]$ before [i]. This palatalization was represented by the letter $j$ in the orthography (hence the spelling Fiji for Viti ). One consequence of the palatalization (Schütz 1978:28) "was to eliminate $t i$ and $d i$ as potential syllables with which to interpret $\mathrm{E}$ [nglish] [t] and [d]. Such a loss was not insignificant; for the other alveolar consonants ( $s$ and $n$ ), $i$ is very highly favored as an added vowel. Since $* t i$ and $* d i$ were not available for Lauan, one might expect te and de as substitutes".

It thus appears that Fijian presents us with an analog to the phenomenon noted by Shinohara (1997) and others for Japanese that is evident in the adaptation of English strike as [sutoraiku]. In Japanese adaptations the inserted vowel is normally [u]; but it systematically appears as [o] after the stops [t] and [d]. This is of course the site of affrication in Japanese phonology: in the native system $/ \mathrm{tu} /$ and $/ \mathrm{du} /$ are realized as $\left[\mathrm{t}^{\mathrm{s}} \mathrm{u}\right.$ ] and $\left[\mathrm{d}^{\mathrm{z}} \mathrm{u}\right]$. Earlier loanwords into Japanese affricate /tu/ (e.g. $t^{s} u u r u u z u<$ Toulouse) while more recent ones (such as Tudei < Today, a car model by Honda) that are less integrated and more faithful to the source retain the stop and hence violate the native phonotactic $*[\mathrm{tu}]$. Aside from a few marginal examples, /tu/ is never adapted as /to/.

There is thus a puzzle. While the epenthetic vowel appears as [o] after/t/, in the adaptation of /tu/ the vowel is stable: either the consonant affricates to satisfy the constraint $*[\mathrm{tu}]$ or both it and the vowel remain unmodified and hence violate the phonotactic constraint. The data in (37) suggest that Lauan Fijian presented a similar state of affairs, summarized in (38)

$$
\begin{aligned}
& \text { Japanese Lauan Fijian } \\
& \text { native: } / \mathrm{tu} /->\quad\left[\mathrm{t}^{\mathrm{s}} \mathrm{u}\right] \quad \text { native: } / \mathrm{ti} /->[\mathrm{t} f \mathrm{i}] \\
& \text { loans: } / \mathrm{tu} /->\left[\mathrm{t}^{\mathrm{s}} \mathrm{u}, \mathrm{tu}, * \text { to }\right] \quad \text { loans: } / \mathrm{ti} /->[\mathrm{t} f \mathrm{i}, \mathrm{ti}, * \mathrm{te}] \\
& / \mathrm{s \# l}->[\mathrm{su}] \quad / \mathrm{s} \# /->[\mathrm{si}] \\
& / \mathrm{t} \# /->\left[* \mathrm{t}^{\mathrm{s}} \mathrm{u}, * \mathrm{tu}, \mathrm{to}\right] \quad / \mathrm{t} \# /->\left[* \mathrm{t} \int \mathrm{i}, * \mathrm{ti}, \mathrm{te}\right]
\end{aligned}
$$

We can resolve this puzzle as follows. Two points seem relevant. First, suppose there is a constraint against $*$ [ti]. The Lauan speaker knows that /ti/ is realized as an affricate before [ $\mathrm{i}$ ]. In adapting a form ending in / $\mathrm{t} \# /$ he knows that a vowel must follow since all syllables are open in Fijian. Minimal Saliency tells him that this vowel should be [i]. But if the adaptation is to sound like a word in Lauan dialect then the following vowel cannot be [i] because / $t$ / is affricated in this context and yet the source word ends in /t\#/ not /t $[$ \#/. He thus concludes that the vowel can't be [i] and so must be the Fijian sound closest to [i], which is [e]. Under this scenario there is thus no sound change 
lowering $/ \mathrm{i} /$ to [e] after $/ \mathrm{t} /$ in Lauan (nor $/ \mathrm{u} /$ to [o] in Japanese). The second relevant point is that, to the extent that it makes sense to view the process of palatalization as a response to the phonotactic *[ti], the response is always to change the consonant, never to change the vowel. (cf. Final Devoicing where the unique solution to $*[\mathrm{~d} \#]$ is devoicing, never nasalization, adding a vowel, etc., Steriade 2001b).

The Similarity model of OT Correspondence (Steriade 2001a,b) claims that faithfulness is evaluated along a dimension of auditory similarity. Similarity judgments derive from a perceptual map that allows speakers to assess the relative similarity of any pair of sounds in a given context. The relative distance is then translated into an analogous ranking of OT faithfulness constraints. In the present context where palatalization of $/ \mathrm{t} /$ is the universally preferred solution to a prohibition against *[i] (change the consonant, not the vowel), we must infer that the change of $/ \mathrm{ti} /$ to $[\mathrm{t} \mathrm{f}]$ is less noticeable than the change of /ti/ to [te]. This implies that the stimulus pair [ti]-[t $\mathrm{j}$ ] should be judged more similar than [ti]-[te]. It suggests that change of palatality in a consonant is less noticeable than change of palatality in a vowel. Hence, we infer the fixed ranking: Ident-[pal]V/t $t^{\mathrm{y}} \_>$Ident-[pal]C/_i. This seems to make phonological sense: a palatality contrast in vowels is preferable to a palatality contrast in consonants. ${ }^{6}$ Given that this ranking is fixed in Universal Grammar, only two of the three relevant candidates in the generic palatalization scenario can be chosen.

\begin{tabular}{|l|l|l|l|}
\hline$/ \mathrm{ti} /$ & $* \mathrm{ti}$ & Ident-[pal] & Ident-[pal]C \\
\hline $\mathrm{ti}$ & $*$ & & \\
\hline $\mathrm{t} \mathrm{i}$ & & & $*$ \\
\hline $\mathrm{te}, \mathrm{tu}$ & & $*$ & \\
\hline
\end{tabular}

[ti] can be chosen (no change) by demoting the markedness constraint *[ti] below the two faithfulness constraints Ident-[pal]V $>>$ Ident-[pal]C. But if the *[ti] constraint is undominated then a phonological change must ensue-either in the consonant or in the vowel. The outcome is determined by whether the faithfulness constraint for the vowel or the consonant is demoted. But if, by hypothesis, the ranking between Ident-[pal]V and Ident-[pal]C is fixed in UG, then Ident-[pal]V can never slip below Ident-[pal]C. The consequence is that change in the vowel will always be penalized and hence blocked in favor of a change in the consonant. Under this conception of faithfulness, the [te], [tu] solutions to palatalization can never emerge as optimal. This formalizes the Natural

\footnotetext{
${ }^{6}$ Compare the situation with nasality where contrast in consonants is more optimal than contrast in vowels.
} 
Phonology hypothesis (Stampe 1980) that /t/ -> [t] / _ [i] is a member of the set of natural phonological processes (palatalization, affrication) while $[\mathrm{i}]->[\mathrm{e}] /[\mathrm{u}] /[\mathrm{t}] \ldots$ is not. $^{7}$

Returning to loanwords, in the adaptation of /ti/ strings into languages that palatalize or affricate the consonant, reliance on the P-Map entails that we can either change the consonant or make no change at all. The vowel should remain unchanged. This prediction seems consistent with the data known to me. ${ }^{8}$ But when the vowel involved lacks a correspondent in the input source then the Ident-[pal]V constraint will not be in play. We might then expect to see a change in the realization of the epenthetic vowel depending on the ranking of *[ti] with respect to the * $\varnothing$-e $>{ }^{*} \varnothing$-i constraints that favor [i] and the (Ident-[pal]V >> Ident-[pal]C that prefers [t]. The tableau in (40) shows the violation profile of the various candidate outcomes.

\begin{tabular}{|l|l|l|l|l|}
\hline$/ \mathrm{t} \# /$ & $* \mathrm{ti}$ & Ident-[pal]C & $* \varnothing-\mathrm{e}$ & $* \varnothing-\mathrm{i}$ \\
\hline $\mathrm{ti}$ & $*$ & & & $*$ \\
\hline $\mathrm{t} \mathrm{i}$ & & $*$ & & $*$ \\
\hline $\mathrm{te}$ & & & $*$ & \\
\hline
\end{tabular}

If $*[\mathrm{ti}]$ is demoted then [ti] is the winner. If Ident-[pal]C is demoted then $[\mathrm{t} \mathrm{j}]$ is the winner. Finally, if Ident-[pal]C remains undominated and the constraint favoring the least salient vowel is demoted, then [te] emerges as the winner. On this view, the variation between the [ti] and [te] realizations of /t\#/ seen in (37) reflects the palatalizing vs. nonpalatalizing dialects, i.e. where * $t i$ is high or low ranked. In palatalizing Lauan *[ti] remains active and $* \varnothing-e$ is demoted allowing [te] as the optimal outcome. In nonpalatalizing dialects, it is *[ti] that is demoted. Ident-[pal]C will reject $[\mathrm{t} f \mathrm{i}]$ and $* \varnothing$-e will reject [te] leaving [ti] as the only viable alternative.

\footnotetext{
${ }^{7}$ The Ident-[pal]V >> Ident-[pal]C can also trigger depalatalization, as in languages such as Lithuanian and Ukrainian where consonants are depalatalized before [i] and [e]. See Padgett 2001 for recent discussion.

${ }^{8}$ For example, in Korean $/ \mathrm{s} /$ is palatalized before $/ \mathrm{i} /$ in both derived and nonderived contexts (Ahn 1998:127): nas-il 'cycle' acc. but naf-i nom. Palatalization is regularly extended to loanwords (Y-J. Kang, p.c.): silk $->$ Silkhi, sit $->\int i t \approx \int i t h i$. In Canadian French (M-H. Côté p.c.) where /t/ and /d/ are affricated before high front vowels, affrication appears in older loans (ticket, steam) but in more recent ones is either variable (tip, pudding) or avoided (meeting, building). Polish is an interesting and systematic exception. As observed in Rubach (1984:65) loans with /i/ after a dental consonant are nativized by retraction of the vowel to $/ \mathbf{i} /$ (orthographic $y$ ): miting 'meeting' $\approx$ mityng, faksimile $\approx$ faksymile 'facsimile'. Retention of the front vowel is found in the speech of educated speakers. Jerzy Rubach (p.c.) points out that the recent loan 'dealer', referring to a car saleman, is adapted as dyler in popular speech with retraction of the [i] to [ $\dot{i}]$. As Rubach observes, Polish grammar restricts dental palatalization to nonderived contexts. The expected adaptation with palatalization [dz]iler is blocked by this superordinate constraint on the Polish lexicon.
} 
Finally, we predict that in those dialects such as Lauan that have palatalization and hence map / $/ \mathrm{i} /$ to $[\mathrm{t} \mathrm{f} \mathrm{i}$ ] and / $\mathrm{t} \# /$ to [te], if the loan source terminates in a palatal $/ \mathrm{t} /$ then the inserted vowel must be /i/. It could not be any other vowel since by hypothesis $/ \mathrm{t} /$ is only found before [i] in this dialect. While the adaptations in the corpus are not of course identified as to the dialect from which they entered the language, the fact is that all adaptations from a final palatal affricate in English that realize the affricate in Fijian (indicated by the spelling with $j$ ) take [i] as the epenthetic vowel.

\begin{tabular}{|c|c|c|}
\hline English & $\underline{\text { Fijian }}$ & \\
\hline March & maji & presumed palatalizing dialect \\
\hline march past & majipasi & \\
\hline charge & jaji & \\
\hline ostrich & ositiriji ${ }^{9}$ & \\
\hline garage & qaraji & \\
\hline spinach & sipi:niji & \\
\hline watch & waji & \\
\hline college & ko:liji & \\
\hline inch & idi & presumed nonpalatalizing dialect \\
\hline hinge & idi & \\
\hline cabbage & ka:veti & \\
\hline cockroach & kokoroti & \\
\hline college & ko:liti & \\
\hline launch & ladi & \\
\hline porridge & po:reti & \\
\hline sausage & so:seti & \\
\hline switch & suwiti & \\
\hline watch & uwati & \\
\hline bandage & va:dreti & \\
\hline
\end{tabular}

Under our analysis, $/ \mathrm{t} / \# /->[\mathrm{t} \mathrm{j}]$ is the only possible outcome. The $/ \mathrm{t} f \# /->\left[\mathrm{t} \int \mathrm{e}\right]$ mapping violates faithfulness for both the consonant (the affricate is only found before [i]) and the vowel ([i] is closer to zero than [e] is) and hence must lose out to $/ \mathrm{t} f \# /->[\mathrm{t} f \mathrm{i}]$. 


\begin{tabular}{|l|l|l|l|}
\hline$/ \mathrm{t} \int \# /$ & $* \mathrm{ti}$ & Ident-[pal]C & $* \varnothing-\mathrm{e}$ \\
\hline$->\mathrm{t} \int \mathrm{i}$ & & & \\
\hline $\mathrm{t} \int \mathrm{e}$ & & $*$ & $*$ \\
\hline
\end{tabular}

One last point can be made. The number of $/ \mathrm{t} \int \# />[\mathrm{ti}] \mathrm{vs}$. $/ \mathrm{t} / />[\mathrm{t} \mathrm{f}]$ mappings in (41) is proportional to the number of $/ \mathrm{t} \# />$ [ti] vs. $/ \mathrm{t} \# /->$ [te] mappings in (37). This is what we expect if two just different grammars are at play: a palatalizing dialect like Lauan where *[ti] ranks high and /ti/ maps to [t $\mathrm{j} \mathrm{i}]$ while /t\#/ maps to [te] and a nonpalatalizing dialect where /ti/ surfaces unchanged and by hypothesis / $t \# /$ is realized as [ti].

\section{Adaptation of Voiced Stops}

In Fijian's close neighbor Tongan (Schütz 1970) the stop system consists of a voiceless series $[\mathrm{p}, \mathrm{t}, \mathrm{k}]$ and a nasal series $[\mathrm{m}, \mathrm{n}, \mathrm{y}]$. As expected, in loanword adaptation from English voiceless stops are paired with Tongan $[\mathrm{p}, \mathrm{t}, \mathrm{k}]$ and nasals are paired with $[\mathrm{m}, \mathrm{n}$, Đ]. English voiced stops are adapted as voiceless stops.

$\begin{array}{lll}\text { English } & & \text { Tongan } \\ \text { pass } & \text { paasi } \\ \text { tea } & \text { tii } \\ \text { card } & \text { ka?ate } \\ \text { mongoose } & \text { mooyokuusi } \\ \text { noble } & \text { noopele } \\ \text { bar } & \text { paa } \\ \text { deacon } & \text { tiikoni } \\ \text { guinea } & \text { kini } \\ & \\ \text { library } & \text { laipeli } \\ \text { commodore } & \text { kamatoa } \\ \text { leghorn } & \text { lekone }\end{array}$

${ }^{9}$ Ositeriji is expected. 
Fijian has a prenasalized series of stops $\left[{ }^{\mathrm{m}} \mathrm{b},{ }^{\mathrm{n}} \mathrm{d},{ }^{\mathrm{g}} \mathrm{g}\right]($ spelled $b, d, q)$ in addition to the voiceless $[\mathrm{p}, \mathrm{t}, \mathrm{k}]$ and nasal $[\mathrm{m}, \mathrm{n}, \mathrm{y}]$. Just as in Tongan, in Fijian adaptations from English voiceless stops are paired with $[\mathrm{p}, \mathrm{t}, \mathrm{k}]$ and nasals with $[\mathrm{m}, \mathrm{n}, \mathrm{y}] .{ }^{10}$

$\begin{array}{ll}\text { English } & \text { Fijian } \\ \text { pipe } & \text { paipo, vaivo } \\ \text { paper } & \text { pepa, veva } \\ \text { taffeta } & \text { ta:feta } \\ \text { coat } & \text { kote } \\ \text { cook } & \text { kuka } \\ \text { khaki } & \text { ka:ki: } \\ \text { manure } & \text { maniwa } \\ \text { pneumonia } & \text { niumo:nia } \\ \text { cream } & \text { kirimu } \\ \text { cabin } & \text { ke:bini } \\ \text { pingpong } & \text { pigipogo }\end{array}$

But English voiced stops have mixed behavior in Fijian adaptations: they are paired with voiceless stops word-medially and finally but with prenasals word-initially.

word-initial

$\begin{array}{llll}\text { English } & \text { Fijian } & & \\ \text { balloon } & \text { baluni } & {\left[{ }^{\mathrm{m}} \mathrm{b}\right]} & 48 \text { examples } \\ \text { bucket } & \text { po:kete } & {[\mathrm{p}]} & 5 \\ \text { desk } & \text { desi } & {\left[{ }^{\mathrm{n}} \mathrm{d}\right]} & 29 \\ \text { devil } & \text { te:voro } & {[\mathrm{t}]} & 4 \\ \text { gambling } & \text { qabiligi } & {\left[{ }^{\mathrm{n}} \mathrm{g}\right]} & 15 \\ \text { grass } & \text { karasi } & {[\mathrm{k}]} & 9\end{array}$

word-medial

$\begin{array}{ll}\text { rabbi } & \text { ra:pai } \\ \text { torpedo } & \text { to:pito } \\ \text { cigar } & \text { sika: }\end{array}$

\footnotetext{
${ }^{10}$ Fijian [p] is an import from English; originally [p] was realized as the approximant [ $\beta$ ] (orthographic $v$ ). Later loans now regularly map [p] to [p].
} 
word-final

$\begin{array}{ll}\text { club } & \text { kalavo } \\ \text { speed } & \text { sipiti } \\ \text { jug } & \text { joke }\end{array}$

Word-medially, the prenasalized series is the regular correspondent of NC clusters in the English source. Final NC clusters have the variable truncation of the stop discussed earlier.

(46) NC clusters

\begin{tabular}{|c|c|}
\hline$\underline{\text { English }}$ & $\underline{\text { Fijian }}$ \\
\hline champion & ja:beni \\
\hline center & seda \\
\hline monkey & maqe \\
\hline account & akaude \\
\hline bank & baqe \\
\hline cucumber & kiukaba \\
\hline brandy & beredi \\
\hline dungaree & daqari \\
\hline bomb $[\mathrm{m}]$ & bomu \\
\hline almond & a:modi \\
\hline ring $\quad[y]$ & rigi \\
\hline
\end{tabular}

The following diagram summarizes the adaptations of the stops.

(47) $\underline{\text { word-medial/final }}$
n nd d t
English
$\left.\right|_{n}$

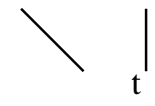
Fijian

word-initial
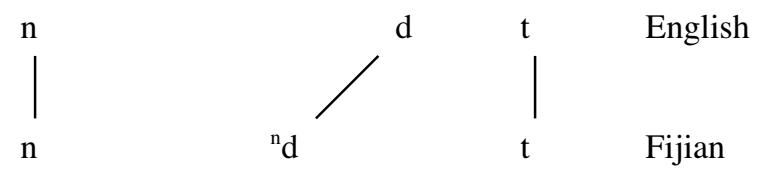
In loanword adaptation, when the recipient language has just a voiceless and a nasal series (as in Tongan) the voiced stops of the donor language appear to invariably map to the former; i.e. we find /d/ adapted as [t] not as [n]. In terms of Steriade's (2001a,b) Similarity model this is the expected outcome. Devoicing is the universally preferred repair of a phonotactic constraint banning word-final [d]. Also, the canonical repair for a language banning voiceless stops after a nasal $(*[n t])$ is to voice the stop. Both processes of Final Devoicing and Post-Nasal Voicing suggest that [t] is [d]'s closest neighbor in phonological space. This would entail the fixed UG ranking of correspondence constraints: Ident-[nasal]C $\gg$ Ident-[voice]C. Under this scenario the Tongan adaptation of English bar must be paa instead of maa.

\begin{tabular}{|l|l|l|}
\hline /bar/ & Ident-[nasal] & Ident-[voice] \\
\hline paa & & $*$ \\
\hline maa & $* !$ & \\
\hline
\end{tabular}

Fijian presents us with an interesting test of this model. Its prenasalized series injects a minimally different range of contrasts into the mix. In medial and final positions the prenasalized series is paired with NCclusters in the English source and the voiced stops are devoiced. From this we infer that prenasalized $\left[{ }^{\mathrm{m}} \mathrm{b},{ }^{\mathrm{n}} \mathrm{d},{ }^{\mathrm{n}} \mathrm{g}\right]$ are closer to clusters than to voiced stops in the P-Map.

$$
\text { nd....... } \mathrm{d} . . . . . . . . . . \mathrm{d} . . . . \mathrm{t}
$$

But when the [nd] cluster is no longer in play (as in word-initial position) then does the structure of the map shift so that $[\mathrm{d}]$ is now closer to $\left[{ }^{\mathrm{n}} \mathrm{d}\right]$ than to [t]? This does not seem very plausible.

In fact, there are hints scattered through the literature on Fijian phonology to suggest that the pairing of English [d] with an initial prenasalized stop is a phonetically accurate judgment. First, Scott (1948:739) observes that the phoneme $b$ "represents a voiced bilabial plosive preceded by the homorganic nasal, mb. The nasal element is not always easily distinguished from the voicing in initial position but is fairly long in medial position”. Second, in a phonetic analysis of the Fijian prenasals Maddieson (1989) reports that the duration of the prenasalized stops is comparable to that of corresponding simple voiceless stops. Furthermore, neither stop series affects the duration of a preceding vowel. Most importantly, Maddieson finds a substantial decrease in the overall duration 
of the prenasal in initial position after pause and concludes (p. 64) that "the short acoustic duration of utterance-initial prenasalized stops ... surely contributes to the lesser salience of the nasal portion of prenasalized stops in initial position".

In his monograph on the history of the study of Fijian, Schütz (1972) discusses the remarks of the Rev. David Cargill, an early missionary ( c. 1835) who wrote a catechism for the Fijians. Schütz notes (p. 16-17) that the catechism "shows Cargill's reaction to his first encounter with the sounds of Fijian. It is apparent that he wrote the translation word by word, for he heard the prenasalized consonants as clusters in the middle of the word (e.g. manda) but as single consonants at the beginning of the word (e.g. bula), even though in phrases the preceding nasal in the latter would be distinctly heard". This point is further supported by misparsings such as Kaloun jina for [Kalou dina] 'true God' in which the nasal component of the (palatalized) prenasal [ $\left.{ }^{\mathrm{n}} \mathrm{d}\right]$ has been incorrectly assigned to the preceding word. It was only later that Cargill realized that these clusters were single phonemes in Fijian. Cargill writes (p. 18) "Each of these consonants does not of itself form a distinct independent sound, but the united effect of each cluster of consonants is one compound sound. Therefore the sound of each combination of consonants must be expressed by one letter; as q to express the sound ngk; $b$ that of mb, $d$ that of nd, and $j$ that of nj." Cargill goes on to say (p. 18): "We at first wrote two consonants where these compound sounds occur, but the natives could not pronounce the two consonants without inserting vowels between them. We therefore substituted one consonant for the two, \& the natives were quite delighted with the improvement, and joyfully exclaimed, 'You have just now known the nature of our language; we are just now able to read the books which you have written' ".

These observations suggest that the nasal component of the Fijian prenasalized stop is not salient without a preceding vowel-particularly for English ears. Hence for all practical purposes the consonants are voiced stops $[\mathrm{b}, \mathrm{d}, \mathrm{g}]$ after a pause. If this is so, then the mapping of English [b, d, g] to these consonants at just the beginning of the word would constitute phonetically veridical perception and not a misperception. They are of course phonologized as prenasals by Fijians since that is the only possible source of a voiced stop in Fijian grammar.

The precarious status of the nasal component of the prenasals in initial position in Fijian has also been recently noted by Erikson (1996) who states (p. 16) "In utteranceinitial position, the nasal portion of the prenasalized stops is shortened, often to the point of deletion. Prenasalized stops are then realized as fully voiced stops." He reports (p. 16) that " The consultant, when asked to repeat a word, would often repeat the word (Fijian) syllable by (Fijian) syllable. A word like batabata: 'cold' came out as [batambata:] when said quickly, but as [ba ta ba ta:] when said slowly". 
The adaptation scenario depicted in (50) sums up our interpretation of the phenomenon. In positions where [d] is barred devoicing will be the preferred realization given the fixed ranking of Ident-[nasal]C $>>$ Ident-[voice]. But in post-pausal position where the nasal portion of the prenasal is attenuated, the Ident-[nasal]C is no longer applicable; Ident-[voice] then chooses the the voiced stop.

\begin{tabular}{|l|l|l|}
\hline /Adam/ & Ident-[nasal]C & Ident-[voice] \\
\hline -> a:tama & & $*$ \\
\hline a: ${ }^{\text {dama }}$ & $* !$ & \\
\hline
\end{tabular}

\begin{tabular}{|l|l|l|}
\hline$/$ desk/ & Ident-[nasal]C & Ident-[voice] \\
\hline tesi & & $* !$ \\
\hline$->^{<\mathrm{n}>}$ desi & & \\
\hline
\end{tabular}

\section{Summary and Conclusions}

In this paper we have reviewed various aspects of the adaptation of loanwords from English into Fijian where the notions of auditory salience and similarity play a major role. We saw that what is probably the most salient property of an English word (its main stress) is faithfully copied in the loan. Various adjustments in length and rhythm are made to accommodate this stress to the metrical system of Fijian. At the opposite end of the saliency scale we saw that the adapter does his best to avoid stressing an inserted vowel (but will do so when this conflicts with the requirement that bans a lapse in stress at either the front or the back end of the word ). The notion of saliency was also crucial to the adaptation of consonant clusters. In general they are repaired by epenthesis; but the last consonant of a word-final cluster is often truncated. A review of the data found that truncation targets consonants whose cues to place of articulation are the weakest. The discussion then passed to the epenthetic vowel. It was found that while it is generally [i], a substantial number of loans occur with [e] after dental stops. Following Schütz (1978) we attributed the [e] to an alternative repair strategy employed in dialects that palatalize [t] before [i]. Assuming that palatalization reflects a phonotactic ban on a/ti/ sequence, it was observed that this is never solved by changing the vowel. To account for this fact a fixed UG ranking of identity constraints based on conjectures of phonetic similarity was postulated. But the epenthetic vowel-because it lacks an input correspondent-can 
change its value to accommodate the phonotactic without violating an identity constraint. The final section examined the puzzling adaptation of voiced stops which devoice medially and finally but are realized as prenasals word-initially. A review of the evidence suggested that Fijian prenasals are realized with attenuation of their nasality after pause and hence the adaptation of $/ d /$ as a prenasal $/{ }^{n} \mathrm{~d} /$ in the face of devoicing elsewhere is a case of veridical perception.

The study of loanword phonology is of theoretical interest because speakers are required to make choices that are not guided by constraints from the native grammar. At a first approximation, the judgments seem to be based on some notion of auditory similarity. More sustained and systematic study of this hypothesis is clearly required. But if it can be sustained it will be a major step forward in understanding an aspect of linguistic competence that has remained puzzling.

\section{References}

Ahn, Sang-Cheol. 1998. An Introduction to Korean Phonology. Seoul: Hanshin Publishing Co.

Alderete, John. 1999. Faithfulness to prosodic heads.

Brasington, Ronald. No Date. Cost and benefit in loanword adaptation. U reading ms.

Broselow, Ellen. 1982. On predicting the interaction between stress and epenthesis.

Glossa 16: 115-32.

Blevins, Juliette. 1994. The bimoraic foot in Rotuman phonology and morphology. Oceanic Linguistics 33, 491-516.

Cohn, Abigail and John McCarthy 1994/1998. Alignment and parallelism in Indonesian phonology. Working Papers of the Cornell Phonetics Laboratory 12, 53-137.

Côté, Marie-Hélène. 2000. Consonant Cluster Phonotactics: a Perceptual Approach. Cambridge, Ma.: MIT Ph.D. dissertation.

Davidson, Lisa and Rolf Noyer. 1996. Loan phonology in Huave: nativization and the ranking of faithfulness constraints. West Coast Conference on Formal

Linguistics $15,65-80$.

Dupoux, E., Kakehi, K., Hirose, Y., Pallier, C., \& Mehler, J. (1999). Epenthetic vowels in Japanese: A perceptual illusion? Journal of Experimental Psychology: Human Perception and Performance, 25(6), 1568--1578.

Elenbaas, Nine and René Kager. 1999. Ternary rhythm and the lapse constraint. Phonology 16, 273-330

Erikson, Blaine. 1996. Issues in Fijian phonology. University of Hawaii Working Papers in Linguistics 28, 13-22. 
Fleischaker, Heidi. 1999. The Location of Epenthetic Vowels with Respect to Consonant Clusters: an Auditory Similarity Account. Los Angeles: UCLA M.A. Thesis:

Gbéto, Flavien. 1999. Les emprunts linguistiques d'origine européene en Fon. Köln: Rüdiger Köppe Verlag.

Green, Thomas and Michael Kenstowicz. 1996. The lapse constraint. Proceedings of the 6th Annual Meeting of the Formal Linguistics Society of the Midwest. 1-15.

Hagstrom, Paul. 1997. Contextual metrical invisibility in Mohawk and Passamaquoddy. MIT Working Papers in Linguistics, 30:113-82

Hayes, Bruce. 1995. Metrical Stress Theory: Principles and Case Studies. Chicago: University of Chicago Press.

Kang, Yoonjung. 2002. Perceptual similarity in loanword adaptation: the adaptation of English post-vocalic word-final stops to Korean.

Kenstowicz, Michael. 1995. Cyclic vs. noncyclic constraint evaluation. Phonology 12, 397-436.

Kenstowicz, Michael. 2001. The role of perception in loanword phonology. Linguistique africaine 20

LaCharité, Darlene and Carole Paradis. 2002. Addressing and disconfirming some predictions of phonetic approximation for loanword adaptation. Langues et linguistique 28, 71-91.

Maddieson, Ian. 1989. Prenasalized stops and speech timing. Journal of the International Phonetic Association 19, 57-66.

Malécot, André. 1960. Vowel nasality as a distinctive feature in American English. Language 36, 222-29.

Padgett, Jaye. 2001. Contrast dispersion and Russian palatalization. Elizabeth Hume and Keith Johnson, eds. The Role of Speech Perception in Phonology. San Diego: Academic Press, pp. 187-218.

Pater, Joe. 2000. Non-uniformity in English secondary stress: the role of ranked and lexically specific constraints. Phonology 17, 143-86.

Prince, Alan and Paul Smolensky. 1993. Optimality Theory.

Rubach, Jerzy. 1984. Cyclic and Lexical Phonology: the Structure of Polish. Dordrecht: Foris Publications.

Schütz, Albert. 1970. Phonological patterning of English loanwords in Tongan. Pacific Linguistic Studies in Honor of Arthur Capell, ed. By S.A. Wurm and D.C. Laycock, 409-28. Pacific Linguistics C-13. Canberra: Australian National University.

Schütz, Albert. 1972. The Languages of Fiji. Oxford; Oxford University Press.

Schütz, Albert. 1978. English loanwords in Fijian. Fijian Language Studies: Borrowing 
and Pidginization, ed. By Albert Schütz, 1-50. Bulletin of Fiji Museum No. 4.

Schütz, Albert. 1983. The accenting of English loanwords in Fijian. Essays in Honor of Charles F. Hockett, ed. By F. Agard, et al. 565-72. Leiden: E.J. Brill.

Schütz, Albert.1985. The Fijian Language. Honolulu: University of Hawaii Press.

Schütz, Albert. 1990. Prosody and its effect of phonological processes in Fijian: a synchronic study. Pacific Island Languages: Essays in Honour of G.B. Milner, ed. By J. Davidson, 119-27. Honolulu: University of Hawai'i Press.

Schütz, Albert. 1999. Fijian accent. Oceanic Linguistics 38, 139-51.

Scott, N. 1948. A study in the phonetics of Fijian. Bulletin of the School of Oriental and African Studies 12, 737-52.

Shinohara, Shigeko. 1997. Analyse phonologique de l'adaptation japonaise de mots étrangers. Thèse de doctorat, Université Paris III. [ROA-243]

Shinohara, Shigeko. 2000. Default accentuation and foot structure in Japanese: evidence from adaptations of French words. Journal of East Asian Linguistics 9, 55-96.

Shinohara, Shigeko. To appear. Emergence of Universal Grammar in foreign word adaptations. Fixing Priorities: Constraints in Phonological Acquisition, ed. By Rene Kager, et al. Cambridge: Cambridge University Press.

Shinohara, Shigeko. 2003. Perceptual effects in segment deletion patterns in loanword phonology. Paris: CNRS UMR 8581

Silverman, Daniel. 1992. Multiple scansions in loanword phonology: evidence from Cantonese. Phonology 9, 289-328.

Stampe, David. 1980. A Dissertation on Natural Phonology. New York: Garland.

Steraide, Donca. 2001a. Directional asymmetries in place assimilation: a perceptual account. The Role of Speech Perception in Phonology, ed by Elizabeth Hume and Keith Johnson, 219-50. San Diego: Academic Press.

Steraide, Donca. 2001b. The phonology of perceptibility effects: the P-map and its consequences for constraint organization. Unpublished UCLA ms.

Wilson, Colin. 2001. Consonant cluster neutralization and targeted constraints. Phonology 18, 147-97. 